\title{
Damned in-laws and other problems
}

\author{
William J. Samarin
}

0. Damned in-laws are not the only problems the Gbeya have. They are, like human beings in every corner of the world and throughout all time, burdened by death and disease, beset by misunderstanding and strife, anxious because of a shortage of food and the means to acquire enough of it. Existentially, man's capacity to conceive problems is infinite; culturally, he is selective. There is a limit to what is thought about and talked about. A leaky roof in a grass-thatched Gbeya house is nothing by comparison with a cantankerous fatherin-law.

\section{Names as discourse}

Personal names, collectively, constitute a discourse about Gbeya problems. Through names the Gbeya talk about their problems. It is a sad story of illness, death, jealousy, animosity, loss of wealth in the payment of brideprice (or the promise of future wealth in the birth of daughters). The names provide the themes for a pessimistic drama that would express the sentiments of Jean-Paul Sartre; they would, in fact, provide some of the dialogue.

Most Gbeya names deal with human relations. 'Damned in-laws' really is a personal name. (The canons of the art of translation permit, if they do not here require, that dấng be rendered by 'damned' or 'good-for nothing' instead of the neutral dictionary referent 'bad'.) The girl or woman who bears this name, as long as she bears it, bears the message of what her father or paternal uncle thinks of her mother's family. The statement will be on the lips of the maternal kin as often as they call out to her, for unlike the Nuer (Evans-Pritchard 1948) Gbeya maternal grandparents do not use another name, one of their own choosing.

The human relations that demand attention to the exclusion of virtually all others are consanguineal and marital. A pair of names mirrors exactly these sets of relations: đã́ng nãm 'Damned relatives' 
(6) and $d$ ấng $k \supset f \varepsilon$ 'Damned in-laws'. For the sake of simplicity we will here examine onomastic discourse by selecting only those names that contain the word nãm 'family'. In my corpus this represents eleven percent of the total: 107 out of 932 names. Nãm always refers to the male line and to males in that line. In fact, practically every name with nãm is a man's name, whereas $k \supset f \varepsilon$ occurs exclusively in women's names. Grammatically, it can be used as a mass noun in the sense of 'family' - or as a count noun - in the sense of 'relative'. When translating into Sango, Gbeya will say ita 'sibling' (also 'cousin') more often than the French borrowing famille. An

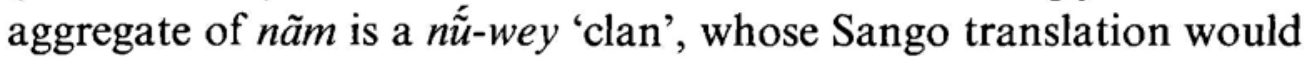
be mará; in Sango this word means 'kind' or 'tribe'.

\section{The syntax of Gbeya names}

Most names consist of at least two morphemes, even in abbreviated forms. Monomorphemic names seem to be nicknames: foro 'Elephant', galon 'Officer's stripes', travaux 'Work' (from travaux publics). The grammatical units that are manifested are either noun

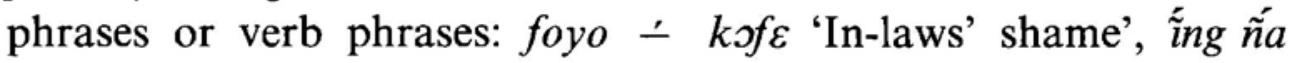
'Don't know'. These verb phrases, as in the latter example, can be independent sentences. And sentences can consist of a predicate with a subject and/or complement: sćre sṍn nã́ 'Spears are not finished off' (that is, they are still useful) or, metaphorically, 'Wars go on'; $e-m$ t $\varepsilon-$ oro 'Leave me at the deserted-village site'. The verbs are either in the imperfective or perfective forms $(54,51)$. Both, however, suggest general truths. A smallish number of names contain verbs in non-predicative form, that is, with a low tone $(4,104)$. I have no satisfactory explanation for these phrases other than that they may be shortened versions of longer names. In Gbeya a lowtoned verb is usually dependent on a preceding noun or verb.

Although it is common for Gbeya names to be sentential, they are syntactically quite simple. This is partly a reflection of the fact that even in ordinary discourse Gbeya clauses are simple. On the other hand, we would not expect frequently used names to be syntactically complex. What is perhaps surprising about Gbeya names, in fact, is that the longish sentential ones are so numerous. 
The explanation may lie in the fact that they tend to be gnomic referring to fundamental truths about life, like sére yú nãm nã 'Spears don't run away from relatives' (95), that is, violence leads to violence.

The proverbial nature of names is found in their content. As far as I know they are never derived from traditional proverbs. In form they resemble proverbs only in the use of the second person plural pronoun that is used in both proverbs and names with a general reference, similar to you in English and on in French. See (32, 33, $35,48,49,50,55,60,74,78)$. For use of the first person pronoun see below.

Ellipsis produces what in normal discourse would be unusual if not ungrammatical constructions. For example, the concept of forgetting always involves the noun $t \tilde{a}$ (whose primary meaning is not clear). The name nãm bió (24) is an abbreviation of $t \tilde{a}-n \tilde{m}$ bió 'Family forgot'. Likewise, verbs generally take some kind of complement in the perfective form, even if it is only the word $m \tilde{\boldsymbol{s}}$ 'thing'. In ordinary discourse nãm gbeá 'Family killed' (47) is not likely to occur except as nãm á gbeá 'it was (my) relative who killed (it or him)'.

Lexically similar names, one of which is shorter than the other, produce ambiguity. Thus, (39) can mean 'Family of death', that is, relatives come to help only at the time of death. But it might be the shortened form of (40), which means 'At death there are no relatives', that is, even at death one does not have the help of relatives. (When there is death in a family, relatives are supposed to come to give moral support, or, as the Gbeya say, to remove shame. They do this by bringing food and gifts; that is, they goy the bereaved. See below for goy.)

The corpus of names was collected when I was living among the Gbeya from 1954 to 1960 in what is now the République Centrafricaine (formerly the territory of Oubangui-Chari of Afrique Equatoriale Française). Most of them are taken from the baptismal registry of the Protestant mission (first Mission Evangélique de l'Oubangui-Chari and then Mission Evangélique Frères) in the Ouahm district, whose administrative center is Bossangoa. The mission was established here in 1926. The names were explained in writing, in Gbeya, by either one of two adult assistants, answering my question: 'Why was this name given?' 


\section{The Gbeya family}

Gbeya names issue from the paternal line. It is either the father or one of his male kin, usually a brother, who suggests the name. The discourse of names is therefore male-oriented. There appears to be no specifically female point of view on any of the names, in spite of the fact that names can be replaced for personal reasons at any time in life. (My principal assistant wanted to be called wiré bó zum $n \tilde{\tilde{a}}$ 'I have no human support' because he was an orphan with only one blood-kin; but because he was a well-known community personnage he continued to be called either by his Gbeya name gũn - te, his Christian name Gédéon, or his nick-name Juge - pronounced žúži - since Gedeon was one of the Old Testament judges.) The only time a name was replaced formally was at the puberty rites. (This was for boys. Excision seems to be a rather recent borrowing from other Gbaya, and I do not think that namechanging took place with girls. Excision, with or without dancing, was taking place in the period 1954-1960, but male puberty rites had disappeared quite some time ago; circumcision was practiced on all boys but clinically at either a government or mission medical center.)

Life's drama is presented in the negative mood. This is explicit in the use of the negative marker $n a \tilde{a}$ and in predicates with a negative connotation. The explanations provided by the assistants certainly take a gloomy point of view. This occurs even when the words of a name would seem to permit another interpretation. For example, nãm zu $-w a$ 'Kind toward them' (83, cf. 107) is an ellipsis of the predicate $d \varepsilon n a \tilde{m} z u-w a$ 'treat them as relatives' or 'be generous to them'. The assistant does not take this in the gnomic sense but as if the predicate were $d \varepsilon$ nãm $z u \doteq w a z \tilde{a} \tilde{a}$ 'one treats them generously in vain'. His explanation was that the name-giver had behaved as a relative should but that his generosity was not even accepted or that it was not accepted gratefully.

In the names one complains because there are no relatives: nãm bó zu-m nã 'I have no relatives' (27; also 31, 32); or because death has wiped the family out, leaving just the father and his new son: nãm dãngá 'The family is ruined' (38; also $63,72,85,86,96)$; but with the new child one proclaims that the family does persist $(28$, 62). If you had relatives, things would be a lot better: nãm kó-i ś́ 
'If you have relatives' $(53$; also $5,29,49,70,78,87)$. But then things aren't like they used to be. In the old days relatives acted like relatives. They fulfilled their obligations: nãm bó kĩne\& nã 'No relatives nowadays' $(30$; also $1,25,35)$. Because my relatives don't come to my help, because they ignore me and aren't kind to me, I have to go to outsiders - people who are not related to me by blood. It's as if I had to go about begging for relatives, a brother here, a brother there: koy nãm 'Borrow relatives' (19; also 14, 16, 44). Ah, but if you have relatives, they are either argumentative and disputatious $(100)$, crafty $(45)$, disunited $(36,100)$, divisive $(103$, 104), disagreeable and disharmonious ( $54-57)$; fickle - because they come only when they want help from my fetish (41), when there's gambling (46), when I have meat (69), and in fact only when someone dies - maybe only at my death! $(39,40)$; forgetful - not remembering that I exist, not writing letters to me $(24,97)$, jealous $(64,88)$, separated and scattered from one another $(18,51,67,79$, $80,99)$, troublesome $(72,73,74,95)$, inhospitable and stingy (58, $84,92,98)$, and violent - fighting and bickering amongst themselves $(47,48,65,71,90,91,93)$.

The behavior and characteristics of the family are revealed in predicates: $b \tilde{\varepsilon}$ 'reject, disclaim' (23); $6 a$ 'disown, renounce' $(4,33$, $34,92)$; $d \varepsilon$ zấng 'do things independently, go one's own way' (36); e rá 'drop (one) flat, disown' (9); ĩng $n \tilde{a}$ 'not recognize, disown' (50); $k \tilde{\rho} n a \tilde{a}$ 'dislike, not agree to' $(20,21,54-57)$; $k p e$ 'close, lock' $(58,98)$; s $\tilde{\varepsilon}$ ' 'dislike' (opposite of $k \tilde{D})(72,73,74,95)$; yay 'pull or take apart' (103); yengi 'shake, agitate' (104).

The list of indictments against one's relatives is long: they are like this or that; they do this and that. Specific reference to oneself is the less common thing, either explicitly in the first person pronoun $(23,27)$ or by implication. In the latter case: 'I'm just a servant of the family' (3); 'I'm considered no kin at all' (2); 'I went and followed my relatives' (8); 'I'm working myself to death for my relatives' (11, $13)$; 'I miss my relatives' $(101,102)$; 'I don't eat relatives' food' (106).

With relatives like those just described, who needs relatives! That's the consternation expressed in nãm - ge ndé 'What kind of a

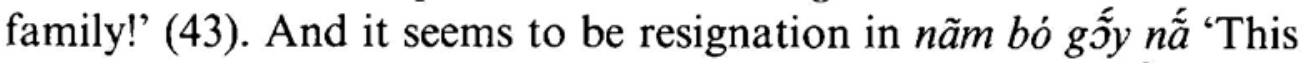
is not being a relative' (26). It certainly is disgust in dấng nãm 'Damned relatives!' (6).

Only a few names express a positive mood; they are at least interpreted positively by the assistants. Yet they reflect the same 
concerns as the other names: one is happy that the relatives are numerous (37), helpful $(60,61,82)$, generous or hospitable (81), and re-united after separation $(66,75,76)$. (Some of the names in the final group might have to do with size of family: 'the family has returned' can have a metaphorical meaning, viz., rise up again after being nearly wiped out by death.) Only one name expresses genuine satisfaction with one's family: 'Family happiness' (15) which is based on the predicate $d \varepsilon g \tilde{\varepsilon}$ wen - nãm 'be happy because of family'. Incidentally, praise figures hardly at all in names. The one example in the corpus now under examination is yoo ti-nãm 'Standing before the family' (105), a woman's name, whose explanation is that a female relative was always available for help; she was there when needed.

In this generally dismal soliloquy on Gbeya family life the picture of the ideal family emerges. It is large; the members live in proximity to one another - in the same village and in fact adjacent to one another; they visit each other, treat each other with hospitality (sharing especially meat and other kinds of food), live peaceably with one another (not arguing or holding grudges), and remain faithful to one another. In times of distress and when threatened by outsiders, they come to one another's support. The picture is one of an ally, not a friend. But the Gbeya word that epitomizes the relative's obligations is not 'help' (tuli gale 'lift up the left hand') but goy. This is a verb for which we have no simple equivalent. We might translate it 'love', except that it implies giving things. An individual establishes during his lifetime several relationships in which there is reciprocal giving (but not formal gift exchanging); family relations, on the other hand, require him to goy his relatives. The verb goy, to my knowledge, never occurs in Gbeya personal names. The reason is perhaps that this kind of behavior is taken for granted or implied in the discourse generally.

\section{A comparative survey of Africa}

Ideal behavior on the part of Gbeya relatives is perhaps not different from what it is in most if not all societies. What is different, of course, is that familial obligations are talked about in this way - 
in personal names. This does not happen everywhere, not even everywhere in Africa. Africans talk about different things in the names they give each other. From a small sample of the literature on this subject, the following topics are identified. The classification is purely ad hoc.

A. Human

a. Personal

(i) Circumstances at birth

Day (Ake Assi, Clamens, Da Cruz, Holas)

Season (Hulstaert)

Place (Hulstaert, Jackson, Lebeuf, Pirovono, Valker)

Co-incidental events (Ittmann)

Order or sequence (Cornevin, Whitehead)

(ii) Qualities, traits, characteristics (Clamens, Da Cruz, Delmond, Ennis, Hulstaert, Lebeuf)

(iii) Experiences: marital (Lebeuf, Vanneste), quarrels (Jackson, Vanneste)

b. Social characteristics: rank (Da Cruz, Pirovono); clan membership (Cornevin, Delmond)

c. Historical, biographical events (Clamens, Delmond, Ennis)

d. Skills, occupations, activities (Hulstaert, Pirovono)

B. Non-human forces, benign and inimical

Fetishes (Ake Assi, Clamens, Cornevin, Holas)

Witchcraft (Jackson)

Totem animals (Pirovono)

C. Ecological (Hulstaert, Lebeuf)

D. Existential, psychological: death, fear, hatred, poverty, solitude, sorrow, sickness, suffering (Beattie, Jackson, Lebeuf, Vanneste)

Whereas a certain number of specific Gbeya names have parallels in other African societies, in other specific ways and in a general way Gbeya names are quite different. This is to be expected, of course; but we need to get beyond the obvious. A careful examination of naming practices and naming discourse ought to reveal patterns for sub-Saharan Africa. In this study we shall have to consider both the content of the names and their use. In the first names are indexical; they are a key to cultural foci. In the second they are a key to social relations.

When names are studied for their indexical function, one must give attention to both the topics and their frequency of occurrence. 
It is surely significant typologically that among the Shona about eighty percent of the names refer to family quarrels, one of whose themes is hatred and death, manifested in topics of witchcraft and infant mortality (Jackson), whereas among the Tagwana, in West Africa, most of the names refer to circumstances surrounding the birth (Clamens). The category of 'circumstances' is, of course, too broad for some purposes. Societies will differ in the circumstances they choose to name. It is, for example, only in West Africa that the specific day of the week figures in naming.

With respect to 'use' a variety of topics must be examined. Names easily and quickly become 'frozen', are treated as units, and are passed on as such. Names can be selected from among those of the ancestors, as in the Cameroun and Gabon (Ittmann, Valker), or ancestral names can be obligatory, as among the Southern Bantu (Munday, Stefaniszyn, Whitehead). Apparently much less frequent than using or having to use names from the ancestral repertoire is the practice of quoting proverbs (Ennis). Here, then, we are concerned with the material out of which names are constructed their source - and the creativity manifested in the naming process, if there is any at all. It is to be understood that constraints always have their influence on creativity. A Kaba whom I knew used to tease the Gbeya in a discreet way about their morbid names. Being himself a Christian and fluent in the Gbeya language, he thought

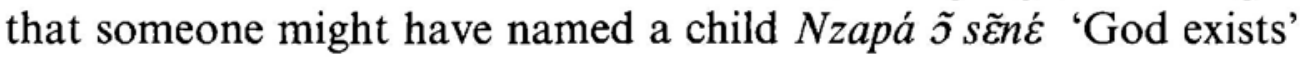
or 'There's God'! This is a comment on the fact that the Gbeya do not do all that they can do with their names. (Although Christianity, in both Catholic and Protestant varieties, is well established among Gbaya-speaking peoples, naming practices have not changed except for adding what is known as either a white man's name or a Godname, that is, yín-Nzapá. It is a matter of personal history, part of which is social evolution in the direction of European or modern culture, whether one is known primarily by his indigenous or his foreign name.)

The use of names includes a consideration of the events that occasion a name, or a new - replacive or additional - name. After birth, names are given in connection with initiation rites, among the Gbeya replacive ones and among the Nuer additive ones (EvansPritchard). Gbeya males formally shed their birth-names at gaza and will become angry enough to fight if the birth-name is used after circumcision. These new names are therefore of different types. The Gbeya differentiate, for example, between a real name and a 
nickname. An example of the latter is gede $-d \tilde{5} \tilde{j}$ 'Shitty ass', which the man must have borne from childhood. Among the Fon a 'pseudonym' is given to oneself at puberty, but a man gives his wife another one after marriage (Da Cruz).

The naming of a name - 'use' in the strictest sense - is limited by various kinds of constraints. One might consider the Gbeya avoidance of precircumcision names a taboo. Respect can also lead to the loss of given names, as among the Gbeya, where teknonymics ('father of so-and-so' and 'mother of so-and-so') can be used for so long that people forget an elder's given or circumcision name. Among the Fon given names are used only in connection with sacrifices (Da Cruz).

Wherever there is a plurality of names there is the possibility of social manipulation: different groups of individuals use different names from the individual's repertoire or the different names, at least some of them, are used by the same persons at different times. Such patterns of behavior are those that sociolinguists look at nowadays when examining the use of pronouns, such as $t u$ and vous and their equivalents, and other lexical items figuring in address systems. But it was a social anthropologist, Evans-Pritchard, who, quite some time ago, wrote about Nuer 'modes of address' instead of personal names as such.

The study of names has not attracted the interest it used to. Although the disregard of any human phenomenon is to be regretted, in this instance we have reason for concern. As African societies change, it will be more and more difficult to reconstruct the past that is alluded to in personal names. Modern urbanized Africans will certainly be out of touch with the kind of life that gave rise to certain names. Moreover, as names are deformed by being subjected to the constraints of European spelling conventions, they become difficult if not impossible to interpret correctly. (Many young Gbeya, for example, have adopted as their proper names those forms which had been transcribed by Europeans, leading in some instances to names that sound like Gbeya ones but are ridiculous or anomalous in meaning.) It is therefore gratifying to find that others are returning to this topic, especially Africans themselves (e. g., Akinnaso 1980, Bean 1980, Ekundayọ 1977, Kimenyi 1978). 


\section{Summary}

By writing about Gbeya personal names I have added to the already considerable body of information on naming practices in Africa, but in doing so, I hope to have made a contribution to our knowledge of an area that is not as well known as some others. I have also suggested ways for conducting comparative onomastic studies, a field that holds much promise. For example, in Gbeya names we find the suggestion for studying male and female relations. Societies where women can give themselves names would be more instructive.

\section{Appendix}

Gbeya personal names relating to nãm 'family, relatives' (with masculine and feminine names distinguished wherever possible).

1. ã́ nãm 'Old-style family' (old family)

2. bó nãm nã́ 'There's no family' or 'I'm just not a relative' (there-is family not)

3. bóy-nãm 'Family servant' (servant [English boy, via Sango from French] [of] family)

4. Ga nãm 'Disown family'

5. dé nãm sé 'Behave like family' (do family then)

6. đấn nãm 'Bad family'

7. dãyá nãm 'Ruined family'

8. don - nãm 'Behind the family' or 'Followed relatives'

9. é nãm rá 'Leave family in the lurch' or 'Drop relatives flat' (leave family rightoff)

10. fara $\doteq$ nãm $(\mathrm{m}$.$) 'Family's place' (place [of] family)$

11. fe fiyo - nãm (m.) 'Die family's fetish' or 'Die for family' (die fetish/death [of] family)

12. fiyo - nãm (f.) 'Family's fetish'

13. fiyo $z u-n a \tilde{m}$ (f.) 'Fetish on the family' or 'Died for family' (fetish head [of] family')

14. gẽne $\doteq$ nãm (f.) 'Stranger to the family' or 'Family of strangers' (stranger [of] family)

15. $g \tilde{\varepsilon} \doteq$ - nãm (m.) 'Family's joy' (joy [of] family)

16. $g \tilde{\varepsilon} \tilde{d i}-n \tilde{a} m$ (f.) 'Strange family' or 'Family of strangers'

17. gũn - nãm (f.) 'Family source' (?) (trunk [of] family)

18. kẽá nãm (m.) 'Divided family'

19. kəy nãm $(\mathrm{m}$.$) 'Beg from family' or 'Borrow relatives'$

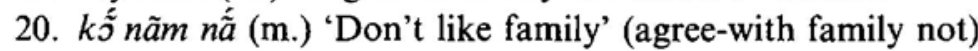

21. kãá nãm (m.) 'Recognized family'

22. mó kj̃ nãm (m.) 'Family’s thing' (thing of family) 
23. nãm $b \tilde{\varepsilon} a ́-m(\mathrm{~m}$.$) 'Family rejected me' (family rejected-me)$

24. nãm bió (f.) 'Family forgot' (see 97)

25. nãm bó 60 nã (m.) 'No more family' (family there-is again not)

26. nãm bó gĩ́y nã $(\mathrm{m}$.) 'Not this kind of family' (family is thus not)

27. nãm bó zu-m ná (m.) 'Have no family' (family there head-my not)

28. nãm bóy (m., f.) 'Family exists'

29. nãm boy sć (m.) 'When there's a family' (family exists then)

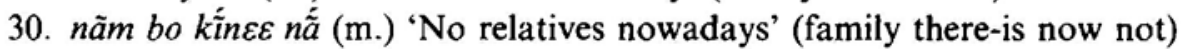

31. nãm bó nấ (f.) 'No family' (family there-is not)

32. nãm bó zu-ì nã (m.) 'You have no family' (family there-is head [of] you (pl.) not)

33. nãm $-6 a-i(\mathrm{~m}$.$) 'Family to reject you' (family [of] reject you)$

34. nãm - 6a ngmãá (m.) 'Disunited family' (family [of] reject each-other)

35. nãm 6ĩná $z u-i$ (m.) 'You still have a family' (family remained head [of] you)

36. nãm $\dashv d \varepsilon z a ́ \eta(\mathrm{m}$.) 'Strange family' or 'Independent relatives' (family [of] do differently)

37. nãm doká (m.) 'Large family' (family has-multiplied)

38. nãm dãyá $(\mathrm{m}$.$) 'Ruined family' (family is-ruined)$

39. nãm - fey (m.) 'Family of death' or 'Relatives just at death'

40. $n \bar{a} m \doteq$ fey bo $\tilde{\boldsymbol{n}}$ (m.) 'No family even at death' (family [of] death there-is not)

41. nãm - fiyo (m.) 'Fetish family' or 'Family for death' (family [of] fetish)

42. nãm gãná (m.) 'Family has surpassed' (possibly informant's analysis of incorrectly spelled name of 64 )

43. nãm - ge ndé (m.) 'What kind of family?' (family [of] what interrogative)

44. nãm géré wi $(\mathrm{m}$.) 'Foreign family' (?) (family [of] any/whatever person)

45. $n \tilde{a} m \doteqdot g \tilde{\varepsilon} r a ́(\mathrm{~m}$.$) 'Crafty relatives'$

46. nãm - gidi (f.) 'Gambling family' (family [of] gambling)

47. nãm gbeá (m.) 'Family killed'

48. nãm $-g b \varepsilon-i$ (m.) 'Family that kills you' (family [of] kills-you)

49. nãm - ho dongo-í ś́ (m.) 'Family behind you' or 'Oh for more relatives' (family [of] pass back [of] you)

50. nãm ĩ́n-ii nã (m.) 'Family doesn't recognize you' (family know-you not)

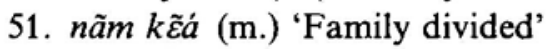

52. nãm kî́ne (m.) 'Family now'

53. nãm $k \dot{-}-i$ s $\dot{\varepsilon}(\mathrm{m}$.) 'When you have your own family' or 'When you have relatives' (family of-you then)

54. nãm $k \tilde{\tilde{\partial}} d \tilde{\tilde{\varepsilon}} \dot{a}$ n $n \tilde{a}(\mathrm{~m}$.) 'Family doesn't like large families' (family likes growth [in numbers] not)

55. nãm $k \tilde{\tilde{o}} m \tilde{\jmath} k \dot{\gamma}-i$ ná $(\mathrm{m}$.) 'Family doesn't like your things' (family like thing ofyou not)

56. $n a \tilde{m} k \hat{\tilde{j}} n \tilde{\tilde{a}}(\mathrm{~m}$.) 'Family doesn't like'

57. nãm $k \tilde{\tilde{\hat{x}}}-i$ nẫ $(\mathrm{m}$.) 'Family doesn't like you'

58. nãm kpeá (f.) 'Family is shut up' (see 98)

59. nãm mấy (m.) 'Family put me out' (?)

60. nãm nẽá $z u-i$ (m.) 'Family went to your help' (family went head [of] you)

61. nãm ndikó (f.) 'Relatives were good'

62. nãm ndiró (m.) 'Family has survived'

63. nãm ndutó (f.) 'Relatives are finished off' 
64. nãm $\rightarrow$ nganda $(\mathrm{m}$.$) 'Jealous family' (family [of] jealousy)$

65. nãm - ngay (m.) 'Strong family' or 'Family with many sons' (family [of] strength)

66. nãm perá (f.) 'Family returned' (see 75)

67. nãm pesá (m.) 'Family has separated' (family has-widened)

68. nãm rengá $(\mathrm{m}$.) 'Family thought about it' (?)

69. nãm - sade (f., m.) 'Family of meat'

70. nãm sé (m.) 'Family first'

71. nãm-sér $\varepsilon$ (m.) 'Warlike family' (family [of] spear)

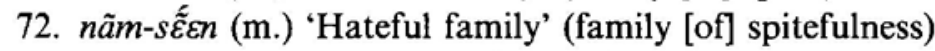

73. nãm $-s \tilde{\varepsilon} n m \tilde{\boldsymbol{s}}(\mathrm{m}$.$) 'Hateful family' (family [of] hate thing)$

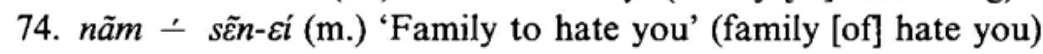

75. nãm sió (m., f.) 'Family returned'

76. nãm sió dọ (m.) 'Family returned' (family returned back)

77. nãm sõná (f.) 'Family's finished off' (family is-finished)

78. $n a \tilde{m}-t \varepsilon-i s \hat{\varepsilon}$ (f.) 'If you had relatives' (family [of] body-your then)

79. nãm yará (f.) 'Family's gone away' or 'Family has divided' (family has-travelled)

80. nãm yẽrá (m.) 'Family's far away' (family is-far)

81. nãm-yỗná (f.) 'Food family' or 'Generous family' ([of] food)

82. nãm zoká (m.) 'Family has seen' or 'Relatives have taken it into account'

83. $n a \tilde{m} z u-w a(\mathrm{~m}$.) 'Kind toward them' (family head-their) (ellipsis, see 5)

84. nãyá nãm 'Not enough for the family' (lacked family)

85. ndongo - nãm (f.) 'Last bit of family' (remaining-portion [of] family)

86. ndúti-nãm (f., m.) 'End of family'

87. ngá nãm (m.) 'Real family'

88. nganda - nãm (m.) 'Family's jealousy' (jealousy [of] family)

89. ngay î́n nãm $(\mathrm{m}$.) 'Strength with family' or 'Sons with family' (?)

90. ngay ĩ nãm (m.) 'Strength knows the family' or 'Sons know the family' (?)

91. ngay zoká nãm $(\mathrm{m}$.) 'Strife has looked on the family' (strength saw family)

92. sére $-6 a$ nãm $(\mathrm{m}$.) 'Strife rejects family' or 'Spear with which to disown relatives' (spear [of] reject family)

93. sćr $-g b \varepsilon$ nãm $(\mathrm{m}$.$) 'Strife kills family' (spear kill family)$

94. sér y yú nãm nã́ (m.) 'Strife doesn't flee the family' (spear flees family not)

95. sร̃́n nãm (f.) 'Dislike your family' (dislike family)

96. sốn koy - nãm (m.) 'Last of the family' (all remainder [of] family)

97. $t \tilde{a}-$ nãm bió (m.) 'Family forgot' (memory [of] family forgot)

98. tí-nãm kpeá (m.) 'Relatives have enclosed themselves' (front [of] family shut)

99. tuwa - nãm (m.) 'Family's home (is far away)' (house [of] family)

100. wen $-\operatorname{nam}(\mathrm{f}$.) 'Family's arguments' (word [of] family)

101. wo - nãm (f.) 'Homesick for family' (hunger [of] family)

102. wo $z u-n \tilde{a} m(\mathrm{~m}$.) 'Family's hunger' (hunger head [of] family)

103. yay nãm (f.) 'Pull apart the family'

104. yengi nãm (f.) 'Shake up the family'

105. yoo tí-nãm (f.) 'Stand before the family' or 'Family's helper' (stand front [of] family)

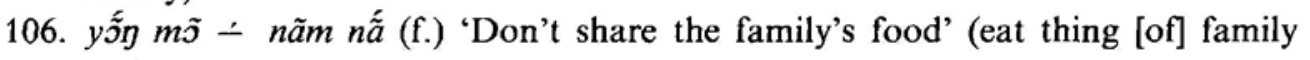
not)

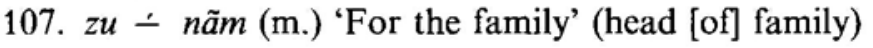




\section{References}

Ake Assi, L. 1954

"Note sur la patronymie baoulé", Notes Africaines de l'Institut Français Noire 64: 115-116.

Akinnaso, F. Niyi

1980 "The sociolinguistic basis of Yoruba personal names", Anthropological Linguistics 22: 275-304.

Bean, Susan S.

$1980 \quad$ "Ethnology and the study of proper names", Anthropological Linguistics 22: $305-316$.

Beattie, J. H. M.

1957 "Nyoro personal names", Uganda Journal 21: 99-106.

Clamens, Gabriel

1950 "Des noms de personnes en dialecte tagwana", Notes Africaines de l'Institut Français d'Afrique Noire 46: 52-54.

Cornevin, $\mathrm{R}$.

1954 "Names among the Bassari", South-Western Journal of Anthropology 10: $160-163$.

Da Cruz, Clément

1956 "Petit recueil des pseudonymes (population Fon, région d'Abomey)", Études Dahoméennes 15: 1-34.

Delmond, P.

1945 [1949] "Quelques observations sur l'état-civil indigène au Soudan occidental", Bulletin de l'Institut Français d'Afrique Noire 7: 54-79.

Ẹkundayọ, S. A.

"Restrictions on personal name sentences in the Yoruba noun phrase", Anthropological Linguistics 19: 55-77.

Ennis, E. L.

1945 "Women's names among the Ovimbundu of Angola", African Studies 4: $1-8$.

Evans-Pritchard, E. E.

1948 "Nuer modes of address", Uganda Journal 12: 166-171.

Holas, B.

1948 "Sur la patronymie Baoulé", Notes Africaines de l'Institut Français d'Afrique Noire 39: 32-33.

Hulstaert, G.

1956 "Noms de personnes chez les Nkundo", Aequatoria 19: 91-102.

Ittmann, Johannes

1954 "Über Kameruner Personennamen [Personal names in the Cameroons]", Afrika und Übersee 39: 19-30.

Jackson, S. K.

1957 "The names of the Vashona", Nada 34: 116-122.

Kimenyi, Alexandre

1978 "Aspects of naming in Kinyarwanda", Anthropological Linguistics 20: $258-271$.

Lebeuf, Jean-Paul

1939 "Le nom chez les Fali", Journal de la Société des Africanistes 9: $103-117$. 


\section{William J. Samarin}

Munday, J. T.

1956 "Bantu name difficulties", Northern Rhodesia Journal 3: 8-13.

Pirovano, G.

1957 "I cognomi nella tribu dei Macua [Names among the Makua]", Missioni della Consolata 16-17.

Relly, Henri

1945

"Quelques notes sur les noms et titres du Grassfield", Bulletin de la Sociéte des Études Camerounaises 10: 77-83.

Samarin, William J.

1965 "The attitudinal and autobiographic in Gbeya dog names", Journal of African Languages 4: 57-72.

1966 The Gbeya Language: Grammar, Texts, and Vocabularies (University of California Publications in Linguistics, Vol. 44) (Berkeley and Los Angeles: University of California Press).

Stefaniszyn, B.

1954 "African reincarnation re-examined", African Studies 13: 131-146.

Valker, André R.

1956 "Remarques sur les noms propres gabonais", Bulletin de l'Institut des Études Centrafricaines 11: 81-90.

Vanneste, M.

1948 "Persoonsnamen bij de Alur in Belgisch Kongo [Personal names of the Alur in the Belgian Congo]", Kongo-Overzee 14: 129-143, 193212.

Whitehead, G. O.

"Personal names amongst the Bari", Man 47: 45-46. 